\title{
Flavonoids Regulate Inflammation and Oxidative Stress in Cancer
}

\author{
Guangxing $\mathrm{Li}^{\dagger}{ }^{\dagger}$, Kaiyue Ding ${ }^{\dagger}$, Yanling Qiao, Liu Zhang, Luping Zheng ${ }^{\circledR}$, Taowen Pan and \\ Lin Zhang * \\ Institute (College) of Integrative Medicine, Dalian Medical University, Dalian 116044, China; \\ lgx2020.11.23@gmail.com (G.L.); crystalting97@gmail.com (K.D.); qy1930303@gmail.com (Y.Q.); \\ zliu960904@gmail.com (L.Z.); lp.zheng@siat.ac.cn (L.Z.); pantw@dmu.edu.cn (T.P.) \\ * Correspondence: linzhang@dmu.edu.cn \\ + These authors contributed equally to this work. \\ Academic Editor: Nawaf Al-Maharik \\ Received: 15 October 2020; Accepted: 16 November 2020; Published: 30 November 2020

\begin{abstract}
Cancer is the second leading cause of death globally. Millions of persons die due to cancer each year. In the last two decades, the anticancer effects of natural flavonoids have become a hot topic in many laboratories. Meanwhile, flavonoids, of which over 8000 molecules are known to date, are potential candidates for the discovery of anticancer drugs. The current review summarizes the major flavonoid classes of anticancer efficacy and discusses the potential anti-cancer mechanisms through inflammation and oxidative stress action, which were based on database and clinical studies within the past years. The results showed that flavonoids could regulate the inflammatory response and oxidative stress of tumor through some anti-inflammatory mechanisms such as NF- $\mathrm{kB}$, so as to realize the anti-tumor effect.
\end{abstract}

Keywords: flavonoid; anti-cancer; inflammation; oxidant

\section{Introduction}

In recent years, the incidence of cancer has been increasing year by year. According to the data provided by World Health Organization (WHO), in 2018, there were 18,078,957 new cancer cases and 9,555,027 deaths worldwide [1]. The top three cancers with the highest new cases are lung cancer, breast cancer, and colorectal cancer, and the top three cancers with the highest mortality rates are lung cancer, colorectal cancer, and gastric cancer. The etiology of cancer is very complex, but according to the research, the occurrence of cancer has a great relationship with chronic inflammation and oxidation. Studies have shown that $20 \%$ of cancers are linked to inflammation [2]. In general, when inflammation occurs in the body, inflammation can regulate pathological and physiological signals of the body by affecting a variety of cells and factors, so as to promote the development of balance towards tissue repair and the elimination of inflammation. At the same time, inflammation is an adaptive response of the body. However, cancer is associated with chronic inflammation [3]. Chronic inflammation can promote the development of cancer, while tumor-induced inflammation can further accelerate the development of cancer [4]. Chronic inflammation can cause cancer in a number of ways. For example, chronic inflammation is often associated with mitochondrial damage [5]. The release of reactive oxygen species (ROS) after mitochondrial injury induces mitochondrial autophagy and leads to cellular functional defects. The overexpression of inflammatory signaling molecules can enhance the anti-apoptosis ability of cells and promote cell growth. NF- $\mathrm{kB}$ is a key regulatory protein in the process of carcinogenesis. Research results in animal models of inflammation-related tumors, such as liver cancer, colorectal cancer, and gastric cancer, have all proven the relationship between NF- $\mathrm{KB}$ and inflammation and tumorigenesis [6]. 
In addition, some studies have shown that patients with malignant tumors are in a low antioxidant state and have elevated oxidative stress levels [7]. High level of ROS plays an important role in the growth, proliferation, invasion, and metastasis of tumor cells [8]. There is abundant ROS in tumor tissues which are infiltrated by inflammatory cells. The use of antioxidants in animal models can effectively block the oxidative damage of DNA caused by ROS and the occurrence of malignant tumors [9]. Meanwhile, ROS can promote the activation of procarcinogens, such as aflatoxin, estrogen, and aromatic hydrocarbons, and cause DNA damage [10,11], which exacerbates the development of cancer.

Nowadays, the treatment options for cancer are surgery, chemotherapy, radiation therapy, immunotherapy, and palliative care, but chemotherapy remains the main treatment. At present, chemotherapeutic drugs are mainly divided into two categories: cytotoxic drugs and non-cytotoxic drugs. The cytotoxic drugs mainly include cisplatin, paclitaxel, and vinblastine, etc. The non-cytotoxic drugs mainly include targeted drugs and hormone drugs, etc. However, cytotoxic drugs not only kill cancer cells, but also harm normal cells. The toxic reaction has become a factor of concern for drug dosage, and also affects the quality of life of patients. For example, bone marrow suppression, gastrointestinal reactions, and hair loss are the most common side effects. In addition, although non-cytotoxic drugs are less toxic, there are still some side effects. For example, small molecule kinase inhibitors are highly specific, but they still have gastrointestinal reactions.

In recent years, treatment of cancer with flavonoids have attracted more and more attention for its low toxic or side effects. Flavonoids now refers to a series of compounds which are connected with three carbon atoms in the center and two benzene rings with phenolic hydroxyl group. Structurally, flavonoids include 2-phenylchromans and 3-phenylchromans. The 2-phenylchromans are flavonoids which contain flavanones, flavones, flavonols, flavanol, and anthocyanidins, while 3-phenylchromans are isoflavones [12]. The structural formulae of flavonoids is shown in the Figure 1 below. According to existing researches, flavonoids have lots of benefits, such as anti-cancer [13], anti-inflammatory [14], antioxidant [15], and anti-cardiovascular disease [16], etc.<smiles>O=C1C[C@H](c2ccccc2)Oc2ccccc21</smiles>

Flavanone<smiles>O=c1cc(-c2ccccc2)oc2ccccc12</smiles>

Flavone<smiles>O=C1c2ccccc2O[C@H](c2ccccc2)[C@@H]1O</smiles>

Flavanonole<smiles>O=C1/C(=C/c2ccccc2)Oc2ccccc21</smiles>

Aurone<smiles>O=C(/C=C/c1ccccc1)c1ccccc1</smiles>

Chalkone<smiles>OC1Cc2ccccc2OC1c1ccccc1</smiles>

Flavanole<smiles>O=c1c(-c2ccccc2)coc2ccccc12</smiles>

Isoflavone<smiles>[R]c1cc2c([R5])c([R6])c([R])cc2[o+]c1-c1cc([R])c([R4])c([R3])c1</smiles>

Anthocyanidine

Figure 1. Structural formulae of flavonoids.

We will mention the following flavonoid substances and their structural formulas:

\section{Classify}

\subsection{Lung Cancer}

Lung cancer has the highest incidence and fatality rate worldwide, and a five-year survival rate is only about $15 \%$ at all stages [17]. Lung cancer is divided into small cell lung cancer and non-small cell lung cancer, of which non-small cell lung cancer accounts for $85 \%$ [18]. Nowadays, the treatment 
of lung cancer is targeted therapy, immunotherapy, and chemotherapy, of which chemical therapy is indispensable, and the chemical drugs currently used include platinum drugs, anti-metabolic drugs, vincristine (VCR), and paclitaxel, etc. At present, the recommended treatment for first-line chemotherapy is a two-drug solution containing platinum [19]. However, studies have found that chemical drugs have significant side effects, e.g., platinum has neurotoxic effects [20], which greatly limits the use of lung cancer treatment. Flavonoids derived from food can largely avoid this problem. Studies have suggested that peonidin 3-glucoside (P3G), as a kind of flavonoids, can inhibit lung cancer cells in a variety of ways, such as lowering the extracellular signal-regulated kinase (ERK) pathway to inhibit $\mathrm{H} 2199$ cell invasion, inhibiting the mitogen-activated protein kinase (MAPK) pathway and regulating extracellular matrix $(E C M)$ degradation protease to inhibit the invasion and activity of lung cancer cells. Moreover, experiments have confirmed that P3G has no toxic effect [21]. Eicosanoid which produced by arachidonic acid (AA) with lysyl oxidase (LOX) metabolism is related to cancer. Baicalein can induce H460 apoptosis by inhibiting 12-LOX [22]. Kaempferol can inhibit Matrix metalloproteinase (MMP)-2 activity of human A549 lung cancer cells [23]. Icaritin can be regulated by microRNA-10a the phosphatase and tensin homolog deleted on chromosome ten (PTEN/Akt) and extracellular signal-regulated kinase (ERK) pathway to inhibit human A549 lung cancer cells [24]. Quercetin can play an anti-cancer role in a variety of ways. Youn and others believe that quercetin induces the apoptosis of SH460 cell by inhibiting NF-KB signaling pathways [25]. There have also been many experiments using Western blotting that found quercetin can reduce the expression of the MMP-2. Some studies reported that luteolin is capable of activating ERK MAPK pathway in different cells [26-28]. Therefore, Zhuang Hong et al. speculated that luteolin could slightly increase the activity of the Ras/Raf/MAPK/ERK pathways in double-mutant NSCLC cells [29]. Xueting Cai et al. found that luteolin completely suppressed the necrosis factor alpha (TNFa) induced the activation of nuclear factor $\mathrm{kB}(\mathrm{NF}-\mathrm{kB}) \mathrm{p} 65$ by Western blotting [30]. Chrysin is used to cause an increase in reactive oxygen species (ROS) in A549 cells [31], and ROS can activate AMP-activated protein kinase (AMPK) [32,33].

Experiments by Hsu-Feng $\mathrm{Lu}$ et al. have shown that apigenin can increase the production of ROS and Ca2p in H460 cells and alter the Bcl-2 associated X protein, and B cell lymphoma 2 (Bax/Bcl-2) [34]. Naringenin inhibits proliferation and induces apoptosis of A549 cells by inducing death receptor 5 (DR5) expression in human lung cancer cells and Naringin also be able to inhibit Akt activity and down-regulates MMP-2 and MMP-9 to inhibit migration of A549 cells [35,36]. Inhibiting synergistic activity of MAPKs/activating protein-1 (AP-1)and the inhibitor of NF- $\mathrm{kB}$ kinases(IKKs)/inhibitor kappa $\mathrm{B}(\mathrm{I} \kappa \mathrm{B}) / \mathrm{NF}-\mathrm{KB}$ signaling pathways, naringin attenuates EGF-induced mucin $5 \mathrm{AC}(\mathrm{MUC} 5 \mathrm{AC})$ secretion in A549 cells [37]. Some studies have also shown that (-)-epigallocatechin-3-gallate(EGCG)in green tea is the most biologically active and inhibits the expression of NF- $\mathrm{KB}$ to inhibit lung cancer [38]. C3G in anthocyanidin can inhibit AP-1, MAPK, NF- $\mathrm{KB}$, and Cyclooxygenase-2 (COX-2) while inhibiting the metastasis and growth tumors [39].

\subsection{Breast Cancer}

Breast cancer is the most common malignant tumor in women, and the global cancer morbidity and mortality statistics released in 2018 show that breast cancer has the second highest incidence and fifth mortality rate in the world, accounting for nearly one-fourth of the incidence of malignant tumors in women, and the highest mortality rate [1]. Many flavonoids have therapeutic effects on breast cancer. Ampelopsin can inhibit tumor cell activity and promote apoptosis through reactive ROS and endoplasmic reticulum stress, but has no toxicity to normal mammary epithelial cells (McF-10a) [40]. Wogonin can activate extracellular regulatory protein kinase (ERK) and inhibit pi3K-Akt-Survivin pathway to cause McF-7 cell apoptosis [41]. By inhibiting the expression of COX-2 and cytochrome P450 (CYP 4A), isoliquiritigenin can reduce the secretion of Prostaglandin E2, reduce the phosphorylation level of intracellular the phosphatidylinositol 3-kinase (PI3K), phosphoinositide-dependent protein kinase 1 (PDK) and Akt, and thus inhibit the migration, invasion and apoptosis resistance of MDA-MB-231 and BT-549 cells [42]. Silibinin induces McF-7 cell death in two ways: on the one 
hand, it down-regulates Estrogen receptors alpha (ER $\alpha)$, thus increasing pro-apoptotic autophagy downstream and leading to cell death. On the other hand, pro-survival ROS/RNS are upregulated, and ROS/reactive nitrogen species (RNS) and autophagy production form a negative feedback loop whose balance is regulated by $\operatorname{Er} \alpha$ [43]. Hesperetin induced apoptosis of McF-7 cells through ROS accumulation and activation of the apoptosis signal-regulating kinase 1 (ASK1)/c-Jun-N-terminal kinase (JNK) pathway [44]. Some studies have found that the daidzein can be combined with R-and S-equol to reduce MMP-2 to suppress the invasion of MDA-MB-231 human breast cancer cells [45]. In vitro cell studies have shown that genistein has anti-tumor effects through multiple pathways, such as NF- $\mathrm{KB}$, JNK, and ERK signaling pathways, which may be involved in the process of genistein inducing the apoptotic signals in MDA-MB-231 cells. EGCG inhibits the metastasis of breast cancer cells by restoring the balance between MMP and the substring matrix-metalloproteinase inhibitor (TIMP) [46]. Shannaiphenol induces apoptosis by inhibiting the expression and function of the estrogen receptor $\mathrm{ER} \alpha$, lowering the expression of polo-like kinase 1 (PLK-1), and exciting continuously ERK signaling paths to inhibit the proliferation of MCF-7 cells in human breast cancer [47-49]. Nar is a potential PI3K inhibitor and mitogen-activated protein kinase(MEK)inhibitor, which inhibits the activity of phosphatidylinositide 3-kinase (PI3K) which is a key regulator of GLUT4 translocation induced by insulin and suppress the phosphorylation of impaired downstream signaling molecule Akt and the proliferation of McF-7 breast cancer cells by inhibiting the uptake of glucose [50].

In addition, the synthetic LW-214 down-regulates the trX-1 (Thioredoxin-1) protein then increases intracellular ROS and activates apoptosis signal-regulated kinase 1 (ASK1), leading to the activation of C-Jun amino-terminal kinase (JNK) and induce cell apoptosis through the mitochondrial pathway [51]. In studies, oncamex, a second-generation flavonoid derivative of myricetin, has a stronger anti-tumor activity than myricetin, which causes apoptosis by regulating changes in ROS in mitochondria in a variety of breast cancer cells, including MCF-7 and MDA-MB-231, etc. [52]. Synthetic LGF-500 also inhibits the invasiveness of MDA-MB-231 cells by inhibiting the PI3K/Akt/NF- $\mathrm{kB}$ signaling pathway [53]. Moreover, some studies show that the IC50 value of quercetin against MCF-7 cells was $0.87 \mathrm{mg} / \mathrm{mL}$ [54].

\subsection{Gastric Cancer}

Gastric cancer is a malignant tumor that occurs in the epithelial of the stomach mucosa and the cause is complex. However, helicobacter pylori infection, environmental factor and genetic factor have become recognized as the cause. In the treatment methods, 5-Fluorouracil (5-Fu), capecitabine, and tecchio were generally selected as the chemical drugs, and the combined drug was generally more effective than the single drug. However, there is no ideal compatibility of medicines. Flavonoids play an important role in the treatment of gastric cancer.

In gastric cancer cell lines, hesperetin inhibits cell proliferation and induces apoptosis by promoting intracellular ROS accumulation [55]. The treatment of human gastric cancer cell (BGC-823) with genistein showed significant decrease in COX-2 protein levels and nuclear transcription factor NF- $\kappa B$ activity. Further studies demonstrated that genistein inhibited tumor angiogenesis by inhibiting NF- $\mathrm{kB}$ activity and COX-2 protein expression [56]. Kham et al. found that genistein significantly inhibited the NF- $\mathrm{kB}$ pathway in mouse skin inflammation, showing strong anti-inflammatory and anti-tumor activity [57]. Naringenin can significantly inhibit the growth of human gastric cancer cells (SGC-7901), reduce the expression of MMP-2 and MMP-9 in gastric cancer cells, and significantly suppress the proliferation, adhesion, invasion, and migration of SGC-7901 [58].

\subsection{Colorectal Cancer}

In recent years, the incidence of CRC has been on the rise in most countries in the world, especially in China where the number of new cases has been increasing at a rate of $4 \%$ year. It is generally believed that its pathogenesis is related to environmental and genetic factors. Studies have found that EGCG in tea can induce hT-29 cell apoptosis via Akt, ERK1/2 and other p38MAPK pathways [59]. The NF-kB pathway plays an extremely important role in the progression from inflammation to cancer in the colon. 
For example, NF-kB-mediated Notch and JNK signaling pathways are also involved in colorectal cancer progression [60]. The downstream NF- $\mathrm{KB}$ signaling pathway is activated when LPS binds specifically to TOLl-like receptor 4 during inflammation. NF- $\kappa B$ is activated when it is transferred from the cytoplasm to the nucleus, and further activates other genes that cause cell proliferation and inhibit apoptosis [61]. Quercetin has been shown to inhibit inflammatory responses and induce the apoptosis of colon cancer Caco-2 and SW-620 cell lines by inhibiting NF- $\mathrm{KB}$ signaling, down-regulating $\mathrm{B}$ cell lymphoma-2 (Bcl-2) and up-regulating Bax [62]. Some also believe that quercetin can induce apoptosis by phosphorylation of AMPK and p53 [63]. In colorectal cancer, baicalein could inhibit cell migration and invasion by reducing the expression of MMP-2 and MMP-9 via suppression of the Akt signaling pathway [64]. According to in vitro studies, the anticancer effect of genistein on colorectal cancer may be related to inhibition of Wnt and NF-kB signaling pathways [65]. Naringenin regulates the expression of cell cycle genes by down-regulating cyclin dependent kinase4 (Cdk4), Cdk6, Cdk7, Bcl-2, X-IAP, and C-IAP-2, and up-regulating the expression of p18, P19, P21, Caspas-3, 7, 8 and 9, Bak, AIF and Bax in cells, so that the cell cycle can stay in the $S$ phase or G2/M phase, and induce the apoptosis of colorectal cancer cells (SW1116, SW837). Meanwhile, the expression levels of cell survival factors PI3K, pAkt, $\mathrm{pI} \kappa \mathrm{B} \alpha$, and NF-kB P65 were also decreased [66].

\subsection{Liver Cancer}

Liver cancer is the most common malignancy of the digestive system with high death rate. Some natural foods and their active ingredients can affect the occurrence and development of liver cancer by inhibiting the growth and metastasis of tumor cells. The study of Li et al. has found that Oroxin $\mathrm{B}(\mathrm{OB})$ can negatively regulate PTEN gene by down-regulating the expression of miR-221 and inactivate the PI3K/Akt signaling pathway [67], while it has been reported that PI3K/Akt pathway plays an important role in regulating inflammatory responses [68]. Baicalein was found that it is able to inhibit the proliferation of Bel-7402 cells by inducing cell cycle arrest at the $S$ and G2/M phase via up-regulating the expression of p21 and p27 and suppressing the PI3K/Akt pathway [69]. Further, there are many pathways that baicalein can fight against hepatocellular carcinoma, such as MAPK and NF- $\kappa B$ pathway, ERK pathway, Akt/mammalian/mechanistic target of rapamycin (mTOR) pathway, etc. [70]. Moreover, isobavachalcone was found to exert anti-proliferative and pro-apoptotic effects on human liver cancer cells by targeting the ERKs/RSK2 signaling pathway [71]. In the study of Liu et al., after fisetin administration and bromocriptine treatment, the expression of TGF- $\beta 1$ was down-regulated in liver cancer cells [72]. Meanwhile TGF- $\beta 1$ is well known in tumor growth, which could be regulated for ERK signaling pathway [73] and the ERK signaling pathway activates TGF- $\beta 1$ expression and leads to tumor metastasis [74]. In addition, it has been reported that, when the IC50 of quercetin is $4.88 \mathrm{mg} / \mathrm{mL}$, the survival rate of HepG2 cell lines can be best reduced [54]. The anticancer effect of xanthohumol induces growth inhibition and apoptosis of human liver cancer through the NF-kB/p53-apoptosis signaling pathway [75]. Galangin and ellagic acid reduced the TPA-induced enzyme activity of matrix metalloproteinase-2(MMP-2) and matrix metalloproteinase-9 (MMP-9) in HepG2 cells [76,77]. It can be seen that flavonoids play an important role in inhibiting the metastasis and development of liver cancer through oxidative stress and anti-inflammatory pathways.

\subsection{Cervical Cancer}

Cervical cancer is the second most common type of cancer and the sixth leading cause of cancer-related mortality in females worldwide. Apigenin is a natural flavonoid, and Josip et al. found that it can inhibit migration and invasion in cervical cancer cells through the elevation of ROS and LPO, and mitochondrial membrane potential's decrease [78]. Quercetin could inhibit anti-apoptotic proteins according to docking studies. Further, quercetin blocks PI3K, MAPK, and WNT pathways [79]. Genistein inhibited the growth of HeLa cells in a dose-dependent and time-dependent manner by modulating the expression of MMP-9 and TIMP-1 [80]. Xanthohumol (XN) and resveratrol uses different mechanisms to induce cell death in cell lines derived from cervical cancer, including NF- $\mathrm{kB}$ and P65 [81,82]. 


\subsection{Prostatic Cancer}

Flavonoids are natural antioxidants found in various foods. Some experimental evidence indicates that flavonoids could prevent prostate cancer. It has many anti-inflammatory or antioxidant mechanisms to promote anti-cancer effects. In the Netherlands Cohort Study, dietary flavonoid intake and black tea consumption were associated with a decreased risk of advanced stage prostate cancer [83]. Venè $\mathrm{R}$ et al. transgenic adenocarcinoma of the mouse prostate (TRAMP) transgenic mice was used as an in vivo model of prostate adenocarcinoma. They observed that the treatment of prostate cancer cells with low micromolar doses of xanthohumol inhibits proliferation and modulates focal adhesion kinase (FAK) and Akt phosphorylation, leading to reduced cell migration and invasion. Oxidative stress by increased production of reactive oxygen species (ROS) was associated with these effects [84]. Sanjeev et al. show that apigenin suppressed prostate tumorigenesis in transgenic adenocarcinoma of the mouse prostate (TRAMP) mice through the PI3K/Akt/FoxO-signaling pathway [85]. Quercetin is considered to be a strong antioxidant that scavenges free radicals and bind transition metal ions. With quercetin treatment, the level of lipid peroxides and $\mathrm{H}_{2} \mathrm{O}_{2}$ were decreased due to its scavenging properties of free radicals, and thereby inhibits prostate cancer initiation [86]. Moreover, quercetin can also increase the activation of PI3K/Akt or RAF/MEK/ERK system and AR mediated growth factor IGF-1/IGF-1R axis to inhibit the development of prostate cancer [87]. The flavonoid apigenin reduces prostate cancer CD44+stem cell survival and migration through PI3K/Akt/NF- $\mathrm{B}$ signaling [88]. Naringenin-induced apoptotic cell death in prostate cancer cells is mediated via the PI3K/Akt and MAPK signaling pathways [89].

\subsection{Other Cancer}

The potential antiproliferative effects of apigenin have been recently evaluated in chemoresistant ovarian cancer cells. Apigenin decreased the viability of both parental and chemoresistant SKOV3 cells through the downregulation of TAM receptor tyrosine kinases expression. It also downregulated their downstream targets Akt and Bcl-xL [90]. Hesperetin suppressed the expression of phosphorylated PI3K/Akt, cyclin D1, MMP-2, and MMP-9 and increased phosphorylated PTEN and p21 in esophageal cancer cells [91]. Phellamurin (Phe) repressed the PI3K/Akt/mTOR pathway in osteosarcoma cells [92].

\section{Discussion}

Table 1 summarized some evidence about the use of flavonoids in cancer. It can be seen from the above that different flavonoids can regulate the inflammatory response and oxidative stress of tumors and play an anticancer role. As is shown in Figure 2 demonstrated the role of major signaling pathways The NF- $\mathrm{BB}$ pathway is the most common pathway for lung cancer, liver cancer and colorectal cancer. Indeed, it has been demonstrated that flavonoids suppress the expression of pro-inflammatory mediators (NF- $\kappa \mathrm{B}$ cascade), have vasodilator activity, improve vascular endothelial function, protect cells against insulin resistance, regulate proliferation, and suppress neuroinflammation by reducing cytokine release [93-100]. NF- $\mathrm{kB} /$ Rel binds to and is inhibited by the IB protein in classical (canonical) signaling pathways. It is generally believed that, under conditions of trauma, low oxygen, and physical and chemical stimulation, the NF- $\mathrm{BB}$ by a large amount of activation and nuclear transport, induced by a variety of cell factors, chemical factors, adhesion molecules, enzymes, and the transcription of antimicrobial peptides, rapidly activates the immune response, which has played central role in inflammation by inhibiting the phosphorylation and degradation of $\kappa B$ predominate $I$ to stop the NF- $\kappa B$ nuclear transfer by inhibiting the p65 subunit to the cell nuclear transfer to prevent the NF- $\kappa B$ and the combination of DNA, etc. The activation of NF- $\mathrm{kB}$ regulates the synthesis of proteins, some of which influence both inflammatory response and tumor formation. The anti-tumor effects of flavonoids are related to anti-free radicals or anti-lipid peroxidation, while most prostate cancer, lung cancer and breast cancer are ROS pathways, which are generally accompanied by cell necrotizing apoptosis. As for the relationship between ROS and tumor, some studies believe that ROS can play a role in mediating 
tumor cell apoptosis [101]. Breast cancer, prostate cancer, liver cancer, and esophageal cancer act on matrix metalloproteinases in another way to inhibit angiogenesis and regulate vascular endothelial growth factor. Angiogenesis is the biological process by which existing blood vessels form new ones. This is a critical process that promotes development, skeletal muscle hypertrophy, menstruation, pregnancy, and wound healing, as well as pathologies such as neovascularization (e.g., retinopathy), rheumatoid arthritis, psoriasis, AIDS/Kaposi sarcoma, and cancer (tumorigenesis) [102,103]. Tumors need a rich blood supply to grow and survive. Newborn blood vessels can make tumor cells along the basal membrane defect space and the substrate to grow around. Further, MMPs expression changes, especially with the higher expression of MMP-2 and MMP-9, and basement membrane degradation of collagen type IV ability enhancement. This is the key step in the cancer cell invasion and metastasis, as a lot of flavonoids of MMP-2 and (or) MMP-9 have an inhibitory effect. Flavonoids regulate the expression of vascular growth factor and block its signal transduction. In addition to these mechanisms, flavonoids could regulate cell apoptosis through the activation of mitogen activated protein kinase (MAPK) signal transduction pathway and protein kinase $\mathrm{C}(\mathrm{PKC})$, which also could inhibit the expression of COX-2 and reduce the induced PGE2 [104].

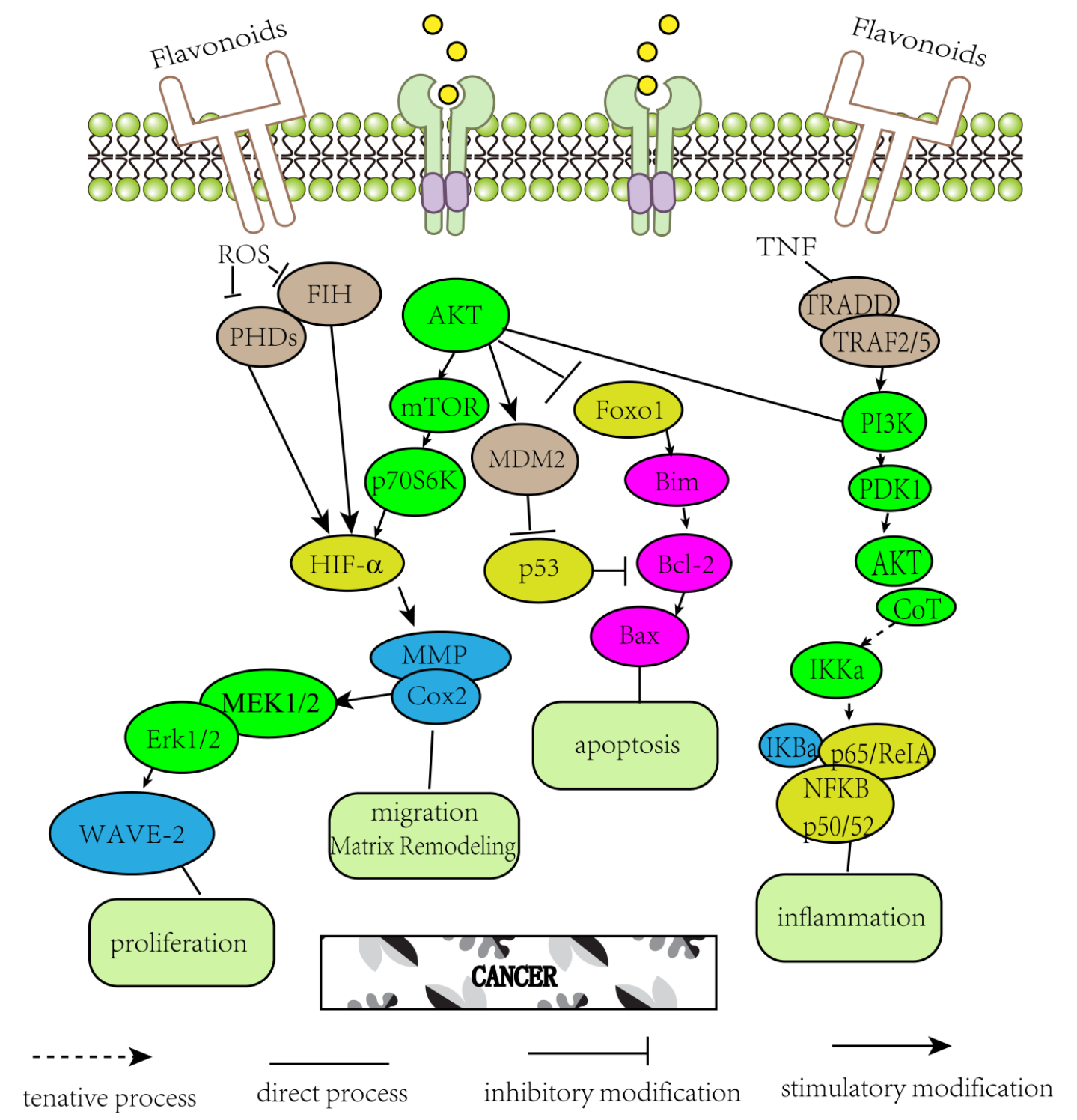

Figure 2. Demonstrated the role of major signaling pathways. 
Table 1. The anti-cancer effects of flavonoids.

\begin{tabular}{|c|c|c|c|c|c|}
\hline Flavonoid & Class & Model & Pathways & Main Effect & References \\
\hline \multicolumn{6}{|c|}{ Lung Cancer } \\
\hline Peonidin 3-Glucoside & Anthocyanidine & cell & LOX & inducing apoptosis & [21] \\
\hline Kaempferol & \multirow{3}{*}{ Flavanonole } & cell & MMP-2 & inducing apoptosis & [23] \\
\hline Epimedium flavin & & cell & PTEN/Akt & inducing apoptosis & [24] \\
\hline Quercetin & & cell & NF-kB/MMP & inducing apoptosis & [25] \\
\hline Luteolin & \multirow{3}{*}{ Flavone } & cell & ERK/MAPK & MAPK pathways activation & [26-29] \\
\hline Luteolin & & cell & NF-kB (p65) & inducing TNF-mediated apoptotic cell death & {$[30]$} \\
\hline Apigenin & & cell & ROS & inducing apoptosis & [34] \\
\hline Naringenin & Flavanone & cell & Akt/MMP & inhibiting tumor growth and metastasis & {$[35,36]$} \\
\hline Epigallocatechin-3-gallate & Flavanole & cell & AP-1, MAPK, NF-KB, and COX-2 & inhibiting tumor growth and metastasis & [38] \\
\hline Baicalein & \multirow{2}{*}{ Flavone } & cell & 12-LOX & inducing apoptosis & [22] \\
\hline Chrysin & & cell & ROS & inducing oxidative stress & {$[31]$} \\
\hline \multicolumn{6}{|c|}{ Breast Cancer } \\
\hline Ampelopsin & Flavanonol & cell & ROS & promoting ER stress & [40] \\
\hline Wogonin & & cell & ERK & inducing apoptosis & [41] \\
\hline Isoliquiritigenin & Chalkone & cell & COX-2/PI3K, PDK, Akt & inhibiting tumor growth and metastasis & [42] \\
\hline Naringenin & \multirow{2}{*}{ Flavanone } & cell & ERK & inhibiting tumor growth & [50] \\
\hline Hesperetin & & cell & ROS & inducing apoptosis & [44] \\
\hline Daidzein & Isoflavone & cell & MMP & inhibiting tumor growth and metastasis & [45] \\
\hline EGCG & Flavanole & cell & MMP & inhibiting tumor growth and metastasis & [46] \\
\hline Kaempferol & Flavanonole & cell & PLK-1/ERK & inhibiting tumor growth and inducing apoptosis & {$[47-49]$} \\
\hline Synthesized flavonoid LW-214 & Flavone & cell & ROS & Induce cell apoptosis through mitochondrial pathway & [51] \\
\hline Synthesized flavonoid Oncamex & Unknown & cell & ROS & Induce cell apoptosis through mitochondrial pathway & [52] \\
\hline Synthesized flavonoid LGF-500 & Flavone & cell & ROS/RNS & inducing apoptosis & [53] \\
\hline \multicolumn{6}{|c|}{ Gastric Cancer } \\
\hline Naringenin & \multirow{2}{*}{ Flavanone } & cell & MMP & inhibiting chemical-induced cell invasion, metastasis & {$[58]$} \\
\hline Hesperetin & & cell & ROS & inhibiting cell proliferation and inducing apoptosis & [55] \\
\hline Genistein & \multirow{2}{*}{ Isoflavone } & cell & NF-kB/COX-2 & inhibiting angiogenesis and metastasis & [56] \\
\hline Genistein & & mouse & $\mathrm{NF}-\mathrm{kB}$ & $\begin{array}{l}\text { suppressing mortality, tumor number, tumor burden } \\
\text { and chemical-induced inflammatory responses }\end{array}$ & [57] \\
\hline
\end{tabular}


Table 1. Cont.

\begin{tabular}{|c|c|c|c|c|c|}
\hline Flavonoid & Class & Model & Pathways & Main Effect & References \\
\hline \multicolumn{6}{|c|}{ Colorectal Cancer } \\
\hline EGCG & Flavanole & cell & ERK1/2/p38MAPK & inducing apoptosis & [59] \\
\hline Quercetin & \multirow{2}{*}{ Flavanonole } & cell & NF-kB & inducing apoptosis & [62] \\
\hline Quercetin & & cell & AMPK/p53 & inducing apoptosis & [63] \\
\hline Baicalein & Flavone & cell & MMP-2/MMP-9/Akt & inhibiting cell migration and invasion & [64] \\
\hline Genistein & Isoflavone & cell & NF-kB & inducing apoptosis & [65] \\
\hline Naringenin & Flavanone & cell & NF-kB/p65 & inducing apoptosis and cell cycle arrest & [66] \\
\hline \multicolumn{6}{|c|}{ Liver Cancer } \\
\hline Oroxin B & \multirow{3}{*}{ Flavone } & cell & PTEN/PI3K/Akt Pathway & fighting against liver cancer & [67] \\
\hline Baicalein & & cell & PI3K/Akt pathway & inhibiting the proliferation of Bel- 7402 cells & [69] \\
\hline Baicalein & & cell & $\begin{array}{l}\text { MAPK and NF-kB pathway, ERK pathway, } \\
\text { Akt/mTOR pathway }\end{array}$ & fighting against hepatocellular carcinoma & [70] \\
\hline Isobavachalcone & \multirow{2}{*}{ Flavanonole } & cell & ERKs/RSK2 signaling pathway & anti-proliferative and pro-apoptotic effects on human liver cancer cells & [71] \\
\hline Fisetin & & cell & TGF- $\beta 1 /$ ERK signaling pathway & down-regulated in liver cancer cells & [72] \\
\hline Xanthohumol & Chalkone & cell & $\mathrm{NF}-\mathrm{kB} / \mathrm{p} 53$ & inducing apoptosis, modulating the NF- $\mathrm{kB} / \mathrm{p} 53$ and the Notch1 signaling pathways & [75] \\
\hline Quercetin & \multirow{2}{*}{ Flavanonole } & cell & ERK & inducing apoptosis & [76] \\
\hline Quercetin & & cell & & suppressing chemical-induced carcinogenesis & [77] \\
\hline \multicolumn{6}{|c|}{ Cervical Cancer } \\
\hline Apigenin & Flavone & cell & ROS and LPO & oxidative stress & [78] \\
\hline Quercetin & Flavanonole & cell & MAPK & decreasing cell proliferation, invasion, angiogenesis & [79] \\
\hline Genistein & Isoflavone & cell & MMP-9 & inducing apoptosis, cell cycle arrest, suppressing cell migration & [80] \\
\hline Xanthohumol & Chalkone & cell & NF-kB & decreasing expression of CXCR4, inhibiting cell invasion induced by CXCL12 & {$[81,82]$} \\
\hline \multicolumn{6}{|c|}{ Prostate Cancer } \\
\hline Xanthohumol & Chalkone & mouse & FAK/Akt/ROS & suppressing tumor growth and progression & [84] \\
\hline Apigenin & Flavone & mouse & PI3K/Akt & suppressing tumor growth, angiogenesis, metastasis & [85] \\
\hline Quercetin & \multirow{2}{*}{ Flavanonole } & mouse & peroxides and $\mathrm{H}_{2} \mathrm{O}_{2}$ got decreased & inhibiting carcinogenesis induced by hormone and carcinogen & [86] \\
\hline Quercetin & & mouse & PI3K/Akt or RAF/MEK/ERK & inhibiting carcinogenesis induced by hormone and carcinogen & [87] \\
\hline Apigenin & Flavone & cell & NF-kB/Akt & inducing apoptosis, inhibiting cell invasion, motility & [88] \\
\hline Naringenin & Flavanone & cell & ERK & invasion and migration & [89] \\
\hline \multicolumn{6}{|c|}{ Ovarian Cancer } \\
\hline Apigenin & Flavone & cell & MMP & Carcinogenesis & [90] \\
\hline \multicolumn{6}{|c|}{ Esophageal Cancer } \\
\hline Hesperetin & Flavanone & cell/mouse & MMP & inhibiting chemical-induced cell invasion, metastasis, & [91] \\
\hline \multicolumn{6}{|c|}{ Osteosarcoma } \\
\hline Phellamurin & Flavanonol & cell & MMP & inhibiting tumor growth and metastasis & [92] \\
\hline
\end{tabular}




\section{Conclusions}

It can be seen that flavonoids can regulate the inflammatory response and oxidative stress of tumors to achieve anticancer effect. However, there are few clinical cases of using flavonoids to treat cancer. Firstly, the oral absorption of flavonoids is slow, the bioavailability is low, and the existing preparation technology of ginkgo flavonoid pellets is in the research and development stage. Secondly, the flavonoid extract is unstable, and it needs to be configured with other complexes. For example, myricetin exhibited substantial limitations, such as poor water-solubility and low stability in the body when it was administrated orally. M10 was produced by adding a hydrophilic glycosylation group and then forming a sodium salt derivative, which exhibited excellent water-solubility $(>100 \mathrm{mg} / \mathrm{mL})$ and better stability in Wistar rat plasma and liver microsomes [105]. Flavonoid drugs will be used in the clinic through technological innovation, which could alleviate the toxic and side effects and drug resistance of Western medicine.

Author Contributions: G.L. and K.D. wrote the manuscript and analyze data. Y.Q., L.Z. (Liu Zhang) collected and collated documents. L.Z. (Luping Zheng) and T.P. edited the graphs. L.Z. (Lin Zhang) revised the manuscript. All authors have read and agreed to the published version of the manuscript.

Funding: This work was financially supported by the National Natural Science Foundation of China (No. 81873195 and 81874305), Liaoning Natural Science Foundation (2019-MS-090 and 20180551286), Liaoning Revitalization Talents Program (XLYC1907113), 2018 program for Liaoning Excellent Talents in University, the project of Dalian Young Star on Science and Technology in 2016 (2017RQ122) and the technology platform project of Educational Department of Liaoning Province- evaluation and transformation of traditional chinese and western medicine in critical disease.

Acknowledgments: This work was financially supported by the National Natural Science Foundation of China (No. 81873195 and 81874305), Liaoning Natural Science Foundation (2019-MS-090 and 20180551286), Liaoning Revitalization Talents Program (XLYC1907113), 2018 program for Liaoning Excellent Talents in University, the project of Dalian Young Star on Science and Technology in 2016 (2017RQ122)and the technology platform project of Educational Department of Liaoning Province-evaluation and transformation of traditional chinese and western medicine in critical disease.

Conflicts of Interest: The authors declare no conflict of interest.

\section{References}

1. Bra, F.; Ferlay, J.; Soerjomataram, I.; Siegel, R.L.; Torre, L.A.; Jemal, A. Global cancer statistics 2018: GLOBOCAN estimates of incidence and mortality worldwide for 36 cancers in 185 countries. CA Cancer J. Clin. 2018, 68, 394-424. [CrossRef] [PubMed]

2. Wang, K.; Karin, M. Tumor-Elicited Inflammation and Colorectal Cancer. Adv Cancer Res. 2015, 128, $173-196$. [PubMed]

3. Pesic, M.; Greten, F.R. Inflammation and cancer: Tissue regeneration gone awry. Curr. Opin. Cell Biol. 2016, 43, 55-61. [CrossRef] [PubMed]

4. Lin, W.W.; Karin, M. A cytokine-mediated link between innate immunity, inflammation, and cancer. J. Clin. Investig. 2007, 117, 1175-1183. [CrossRef]

5. Stathopoulos, G.T.; Sherrill, T.P.; Cheng, D.S.; Scoggins, R.M.; Han, W.; Polosukhin, V.V.; Connelly, L.; Yull, F.E.; Fingleton, B.; Blackwell, T.S. Epithelial NF-kappaB activation promotes urethane-induced lung carcinogenesis. Proc. Natl. Acad. Sci. USA 2007, 104, 18514-18519. [CrossRef]

6. Mantovani, A.; Allavena, P.; Sica, A.; Balkwill, F. Cancer-related inflammation. Nature 2008, 454, 436-444. [CrossRef]

7. Fuchs-Tarlovsky, V. Role of antioxidants in cancer therapy. Nutrition 2013, 29, 15-21. [CrossRef]

8. Kumar, B.; Koul, S.; Khandrika, L.; Meacham, R.B.; Koul, H.K. Oxidative stress is inherent in prostate cancer cells and is required for aggressive phenotype. Cancer Res. 2008, 68, 1777-1785. [CrossRef]

9. Wei, H.; Frenkel, K. Suppression of tumor promoter-induced oxidative events and DNA damage in vivo by sarcophytol A: A possible mechanism of antipromotion. Cancer Res. 1992, 52, 2298-2303.

10. Pereira, C.; Grácio, D.; Teixeira, J.P.; Magro, F. Oxidative Stress and DNA Damage: Implications in Inflammatory Bowel Disease. Inflamm. Bowel Dis. 2015, 21, 2403-2417. [CrossRef]

11. Dutta, K.; Prasad, P.; Sinha, D. Chronic low level arsenic exposure evokes inflammatory responses and DNA damage. Int. J. Hyg. Environ. Health 2015, 218, 564-574. [CrossRef] [PubMed] 
12. Faggio, C.; Sureda, A.; Morabito, S.; Sanches-Silva, A.; Mocan, A.; Nabavi, S.F.; Nabavi, S.M. Flavonoids and platelet aggregation: A brief review. Eur. J. Pharm. 2017, 807, 91-101. [CrossRef] [PubMed]

13. Manthey, J.A.; Guthrie, N. Antiproliferative activities of citrus flavonoids against six human cancer cell lines. J. Agric. Food Chem. 2002, 50, 5837-5843. [CrossRef] [PubMed]

14. Serafini, M.; Peluso, I.; Raguzzini, A. Flavonoids as anti-inflammatory agents. Proc. Nutr. Soc. 2010, 69, $273-278$. [CrossRef] [PubMed]

15. Siah, M.; Farzaei, M.H.; Ashrafi-Kooshk, M.R.; Adibi, H.; Arab, S.S.; Rashidi, M.R.; Khodarahmi, R. Inhibition of guinea pig aldehyde oxidase activity by different flavonoid compounds: An in vitro study. Bioorganic Chem. 2016, 64, 74-84. [CrossRef] [PubMed]

16. Ciumărnean, L.; Milaciu, M.V.; Runcan, O.; Vesa, Ș.C.; Răchișan, A.L.; Negrean, V.; Perné, M.G.; Donca, V.I.; Alexescu, T.G.; Para, I.; et al. The Effects of Flavonoids in Cardiovascular Diseases. Molecules 2020, 25, 4320. [CrossRef]

17. Tang, J.M.; He, Q.Y.; Guo, R.X.; Chang, X.J. Phosphorylated Akt overexpression and loss of PTEN expression in non-small cell lung cancer confers poor prognosis. Lung Cancer 2006, 51, 181-191. [CrossRef]

18. Milligan, S.A.; Burke, P.; Coleman, D.T.; Bigelow, R.L.; Steffan, J.J.; Carroll, J.L.; Williams, B.J.; Cardelli, J.A. The green tea polyphenol EGCG potentiates the antiproliferative activity of c-Met and epidermal growth factor receptor inhibitors in non-small cell lung cancer cells. Clin. Cancer Res. 2009, 15, 4885-4894. [CrossRef]

19. Sakaeda, T.; Kadoyama, K.; Okuno, Y. Adverse event profiles of platinum agents: Data mining of the public version of the FDA adverse event reporting system, AERS, and reproducibility of clinical observations. Int. J. Med. Sci. 2011, 8, 487-491. [CrossRef]

20. Holmes, J.; Stanko, J.; Varchenko, M.; Ding, H.; Madden, V.J.; Bagnell, C.R.; Wyrick, S.D.; Chaney, S.G. Comparative neurotoxicity of oxaliplatin, cisplatin, and ormaplatin in a Wistar rat model. Toxicol. Sci. 1998, 46, 342-351.

21. Ho, M.L.; Chen, P.N.; Chu, S.C.; Kuo, D.Y.; Kuo, W.H.; Chen, J.Y.; Hsieh, Y.S. Peonidin 3-glucoside inhibits lung cancer metastasis by downregulation of proteinases activities and MAPK pathway. Nutr. Cancer 2010, 62, 505-516. [CrossRef] [PubMed]

22. Leung, H.W.; Yang, W.H.; Lai, M.Y.; Lin, C.J.; Lee, H.Z. Inhibition of 12-lipoxygenase during baicalein-induced human lung nonsmall carcinoma H460 cell apoptosis. Food Chem. Toxicol. 2007, 45, 403-411. [CrossRef] [PubMed]

23. Jo, E.; Park, S.J.; Choi, Y.S.; Jeon, W.K.; Kim, B.C. Kaempferol Suppresses Transforming Growth Factor- $\beta 1-$ Induced Epithelial-to-Mesenchymal Transition and Migration of A549 Lung Cancer Cells by Inhibiting Akt1-Mediated Phosphorylation of Smad3 at Threonine-179. Neoplasia 2015, 17, 525-537. [CrossRef] [PubMed]

24. Lu, X.; Xue, B.; Zhang, T.; Zhou, X.; Zhang, Y. Down-regulation of microRNA-10a mediates the anti-tumor effect of icaritin in A549 cells via the PTEN/AKT and ERK pathway. Gen. Physiol. Biophys. 2019, 38, 525-533. [CrossRef]

25. Youn, H.; Jeong, J.C.; Jeong, Y.S.; Kim, E.J.; Um, S.J. Quercetin potentiates apoptosis by inhibiting nuclear factor-kappaB signaling in H460 lung cancer cells. Biol. Pharm. Bull. 2013, 36, 944-951. [CrossRef]

26. Choi, B.M.; Lim, D.W.; Lee, J.A.; Gao, S.S.; Kwon, D.; Kim, B.R. Luteolin suppresses cisplatin-induced apoptosis in auditory cells: Possible mediation through induction of heme oxygenase-1 expression. J. Med. Food 2008, 11, 230-236. [CrossRef]

27. Tufekci, K.U.; Civi Bayin, E.; Genc, S.; Genc, K. The Nrf2/ARE Pathway: A Promising Target to Counteract Mitochondrial Dysfunction in Parkinson's Disease. Parkinsons Dis. 2011, 2011, 314082. [CrossRef]

28. Kim, M.J.; Woo, J.S.; Kwon, C.H.; Kim, J.H.; Kim, Y.K.; Kim, K.H. Luteolin induces apoptotic cell death through AIF nuclear translocation mediated by activation of ERK and p38 in human breast cancer cell lines. Cell Biol. Int. 2012, 36, 339-344. [CrossRef]

29. Hong, Z.; Cao, X.; Li, N.; Zhang, Y.; Lan, L.; Zhou, Y.; Pan, X.; Shen, L.; Yin, Z.; Luo, L. Luteolin is effective in the non-small cell lung cancer model with L858R/T790M EGF receptor mutation and erlotinib resistance. Br. J. Pharm. 2014, 171, 2842-2853. [CrossRef]

30. Cai, X.; Ye, T.; Liu, C.; Lu, W.; Lu, M.; Zhang, J.; Wang, M.; Cao, P. Luteolin induced G2 phase cell cycle arrest and apoptosis on non-small cell lung cancer cells. Toxicol. Vitr. 2011, 25, 1385-1391. [CrossRef]

31. Shao, J.J.; Zhang, A.P.; Qin, W.; Zheng, L.; Zhu, Y.F.; Chen, X. AMP-activated protein kinase (AMPK) activation is involved in chrysin-induced growth inhibition and apoptosis in cultured A549 lung cancer cells. Biochem. Biophys. Res. Commun. 2012, 423, 448-453. [CrossRef] [PubMed] 
32. Cao, C.; Lu, S.; Kivlin, R.; Wallin, B.; Card, E.; Bagdasarian, A.; Tamakloe, T.; Chu, W.M.; Guan, K.L.; Wan, Y. AMP-activated protein kinase contributes to UV- and $\mathrm{H}_{2} \mathrm{O}_{2}$-induced apoptosis in human skin keratinocytes. J. Biol. Chem. 2010, 285, 14842. [CrossRef] [PubMed]

33. Chen, L.; Xu, B.; Liu, L.; Luo, Y.; Yin, J.; Zhou, H.; Chen, W.; Shen, T.; Han, X.; Huang, S. Hydrogen peroxide inhibits mTOR signaling by activation of AMPKalpha leading to apoptosis of neuronal cells. Lab. Investig. 2010, 90, 762-773. [CrossRef] [PubMed]

34. Lu, H.F.; Chie, Y.J.; Yang, M.S.; Lu, K.W.; Fu, J.J.; Yang, J.S.; Chen, H.Y.; Hsia, T.C.; Ma, C.Y.; Ip, S.W.; et al. Apigenin induces apoptosis in human lung cancer $\mathrm{H} 460$ cells through caspase- and mitochondria-dependent pathways. Hum. Exp. Toxicol. 2011, 30, 1053-1061. [CrossRef]

35. Jin, C.Y.; Park, C.; Hwang, H.J.; Kim, G.Y.; Choi, B.T.; Kim, W.J.; Choi, Y.H. Naringenin up-regulates the expression of death receptor 5 and enhances TRAIL-induced apoptosis in human lung cancer A549 cells. Mol. Nutr. Food Res. 2011, 55, 300-309. [CrossRef]

36. Chang, H.L.; Chang, Y.M.; Lai, S.C.; Chen, K.M.; Wang, K.C.; Chiu, T.T.; Chang, F.H.; Hsu, L.S. Naringenin inhibits migration of lung cancer cells via the inhibition of matrix metalloproteinases-2 and -9. Exp. Ther. Med. 2017, 13, 739-744. [CrossRef]

37. Nie, Y.C.; Wu, H.; Li, P.B.; Xie, L.M.; Luo, Y.L.; Shen, J.G.; Su, W.W. Naringin attenuates EGF-induced MUC5AC secretion in A549 cells by suppressing the cooperative activities of MAPKs-AP-1 and IKKs-IкB-NF- $\mathrm{B}$ signaling pathways. Eur. J. Pharm. 2012, 690, 207-213. [CrossRef]

38. Zhang, L.; Xie, J.; Gan, R.; Wu, Z.; Luo, H.; Chen, X.; Lu, Y.; Wu, L.; Zheng, D. Synergistic inhibition of lung cancer cells by EGCG and NF-кB inhibitor BAY11-7082. J. Cancer 2019, 10, 6543-6556. [CrossRef]

39. Ding, M.; Feng, R.; Wang, S.Y.; Bowman, L.; Lu, Y.; Qian, Y.; Castranova, V.; Jiang, B.H.; Shi, X. Cyanidin-3glucoside, a natural product derived from blackberry, exhibits chemopreventive and chemotherapeutic activity. J. Biol. Chem. 2006, 281, 17359-17368. [CrossRef]

40. Zhou, Y.; Shu, F.; Liang, X.; Chang, H.; Shi, L.; Peng, X.; Zhu, J.; Mi, M. Ampelopsin induces cell growth inhibition and apoptosis in breast cancer cells through ROS generation and endoplasmic reticulum stress pathway. PLoS ONE 2014, 9, e89021. [CrossRef]

41. Huang, K.F.; Zhang, G.D.; Huang, Y.Q.; Diao, Y. Wogonin induces apoptosis and down-regulates survivin in human breast cancer MCF-7 cells by modulating PI3K-AKT pathway. Int. Immunopharmacol. 2012, 12, 334-341. [CrossRef] [PubMed]

42. Zheng, H.; Li, Y.; Wang, Y.; Zhao, H.; Zhang, J.; Chai, H.; Tang, T.; Yue, J.; Guo, A.M.; Yang, J. Downregulation of COX-2 and CYP 4A signaling by isoliquiritigenin inhibits human breast cancer metastasis through preventing anoikis resistance, migration and invasion. Toxicol. Appl. Pharm. 2014, 280, 10-20. [CrossRef] [PubMed]

43. Zheng, N.; Liu, L.; Liu, W.W.; Li, F.; Hayashi, T.; Tashiro, S.I.; Onodera, S.; Ikejima, T. Crosstalk of ROS/RNS and autophagy in silibinin-induced apoptosis of MCF-7 human breast cancer cells in vitro. Acta Pharm. Sin. 2017, 38, 277-289. [CrossRef] [PubMed]

44. Palit, S.; Kar, S.; Sharma, G.; Das, P.K. Hesperetin Induces Apoptosis in Breast Carcinoma by Triggering Accumulation of ROS and Activation of ASK1/JNK Pathway. J. Cell Physiol. 2015, 230, 1729-1739. [CrossRef] [PubMed]

45. Magee, P.J.; Allsopp, P.; Samaletdin, A.; Rowland, I.R. Daidzein, R-(+)equol and S-(-)equol inhibit the invasion of MDA-MB-231 breast cancer cells potentially via the down-regulation of matrix metalloproteinase- 2 . Eur. J. Nutr. 2014, 53, 345-350. [CrossRef] [PubMed]

46. Deb, G.; Thakur, V.S.; Limaye, A.M.; Gupta, S. Epigenetic induction of tissue inhibitor of matrix metalloproteinase-3 by green tea polyphenols in breast cancer cells. Mol. Carcinog. 2015, 54, 485-499. [CrossRef] [PubMed]

47. Kang, G.Y.; Lee, E.R.; Kim, J.H.; Jung, J.W.; Lim, J.; Kim, S.K.; Cho, S.G.; Kim, K.P. Downregulation of PLK-1 expression in kaempferol-induced apoptosis of MCF-7 cells. Eur. J. Pharmacol. 2009, 611, 17-21. [CrossRef]

48. Hung, H. Inhibition of estrogen receptor alpha expression and function in MCF-7 cells by kaempferol. J. Cell Physiol. 2004, 198, 197-208. [CrossRef]

49. Kim, B.W.; Lee, E.R.; Min, H.M.; Jeong, H.S.; Ahn, J.Y.; Kim, J.H.; Choi, H.Y.; Choi, H.; Kim, E.Y.; Park, S.P.; et al. Sustained ERK activation is involved in the kaempferol-induced apoptosis of breast cancer cells and is more evident under 3-D culture condition. Cancer Biol. 2008, 7, 1080-1089. [CrossRef]

50. Harmon, A.W.; Patel, Y.M. Naringenin inhibits glucose uptake in MCF-7 breast cancer cells: A mechanism for impaired cellular proliferation. Breast Cancer Res. Treat. 2004, 85, 103-110. [CrossRef] 
51. Pan, D.; Li, W.; Miao, H.; Yao, J.; Li, Z.; Wei, L.; Zhao, L.; Guo, Q. LW-214, a newly synthesized flavonoid, induces intrinsic apoptosis pathway by down-regulating Trx-1 in MCF-7 human breast cells. Biochem. Pharm. 2014, 87, 598-610. [CrossRef] [PubMed]

52. Martínez-Pérez, C.; Ward, C.; Turnbull, A.K.; Mullen, P.; Cook, G.; Meehan, J.; Jarman, E.J.; Thomson, P.I.; Campbell, C.J.; McPhail, D.; et al. Antitumour activity of the novel flavonoid Oncamex in preclinical breast cancer models. Br. J. Cancer 2016, 114, 905-916. [CrossRef] [PubMed]

53. Li, C.; Li, F.; Zhao, K.; Yao, J.; Cheng, Y.; Zhao, L.; Li, Z.; Lu, N.; Guo, Q. LFG-500 inhibits the invasion of cancer cells via down-regulation of PI3K/AKT/NF-KB signaling pathway. PLoS ONE 2014, 9, e91332. [CrossRef] [PubMed]

54. Ahmed, H.; Moawad, A.; Owis, A.; AbouZid, S.; Ahmed, O. Flavonoids of Calligonum polygonoides and their cytotoxicity. Pharm. Biol. 2016, 54, 2119-2126. [CrossRef] [PubMed]

55. Zhang, J.; Wu, D.; Vikash; Song, J.; Wang, J.; Yi, J.; Dong, W. Hesperetin Induces the Apoptosis of Gastric Cancer Cells via Activating Mitochondrial Pathway by Increasing Reactive Oxygen Species. Dig. Dis. Sci. 2015, 60, 2985-2995. [CrossRef]

56. Ma, Y.; Wang, J.; Liu, L.; Zhu, H.; Chen, X.; Pan, S.; Sun, X.; Jiang, H. Genistein potentiates the effect of arsenic trioxide against human hepatocellular carcinoma: Role of Akt and nuclear factor-кB. Cancer Lett. 2011, 301, 75-84. [CrossRef]

57. Khan, A.Q.; Khan, R.; Rehman, M.U.; Lateef, A.; Tahir, M.; Ali, F.; Sultana, S. Soy isoflavones (daidzein \& genistein) inhibit 12-O-tetradecanoylphorbol-13-acetate (TPA)-induced cutaneous inflammation via modulation of COX-2 and NF- $\mathrm{kB}$ in Swiss albino mice. Toxicology 2012, 302, 266-274.

58. Bao, L.; Liu, F.; Guo, H.B.; Li, Y.; Tan, B.B.; Zhang, W.X.; Peng, Y.H. Naringenin inhibits proliferation, migration, and invasion as well as induces apoptosis of gastric cancer SGC7901 cell line by downregulation of AKT pathway. Tumour. Biol. 2016, 37, 11365-11374. [CrossRef]

59. Cerezo-Guisado, M.I.; Zur, R.; Lorenzo, M.J.; Risco, A.; Martín-Serrano, M.A.; Alvarez-Barrientos, A.; Cuenda, A.; Centeno, F. Implication of Akt, ERK1/2 and alternative p38MAPK signalling pathways in human colon cancer cell apoptosis induced by green tea EGCG. Food Chem. Toxicol. 2015, 84, 125-132. [CrossRef]

60. Lin, G.; Tang, Z.; Ye, Y.B.; Chen, Q. NF-кB activity is downregulated by KRAS knockdown in SW620 cells via the RAS-ERK-IкB $\alpha$ pathway. Oncol. Rep. 2012, 27, 1527-1534.

61. Rakoff-Nahoum, S.; Medzhitov, R. Regulation of spontaneous intestinal tumorigenesis through the adaptor protein MyD88. Science 2007, 317, 124-127. [CrossRef] [PubMed]

62. Zhang, X.A.; Zhang, S.; Yin, Q.; Zhang, J. Quercetin induces human colon cancer cells apoptosis by inhibiting the nuclear factor-kappa B Pathway. Pharmacogn. Mag. 2015, 11, 404-409. [CrossRef] [PubMed]

63. Kim, H.J.; Kim, S.K.; Kim, B.S.; Lee, S.H.; Park, Y.S.; Park, B.K.; Kim, S.J.; Kim, J.; Choi, C.; Kim, J.S.; et al. Apoptotic effect of quercetin on HT-29 colon cancer cells via the AMPK signaling pathway. J. Agric. Food Chem. 2010, 58, 8643-8650. [CrossRef] [PubMed]

64. Rui, X.; Yan, X.I.; Zhang, K. Baicalein inhibits the migration and invasion of colorectal cancer cells via suppression of the AKT signaling pathway. Oncol. Lett. 2016, 11, 685-688. [CrossRef] [PubMed]

65. Luo, Y.; Wang, S.X.; Zhou, Z.Q.; Wang, Z.; Zhang, Y.G.; Zhang, Y.; Zhao, P. Apoptotic effect of genistein on human colon cancer cells via inhibiting the nuclear factor-kappa B (NF-kB) pathway. Tumour. Biol. 2014, 35, 11483-11488. [CrossRef] [PubMed]

66. Abaza, M.S.; Orabi, K.Y.; Al-Quattan, E.; Al-Attiyah, R.J. Growth inhibitory and chemo-sensitization effects of naringenin, a natural flavanone purified from Thymus vulgaris, on human breast and colorectal cancer. Cancer Cell Int. 2015, 15, 46. [CrossRef]

67. Li, N.; Men, W.; Zheng, Y.; Wang, H.; Meng, X. Oroxin B Induces Apoptosis by Down-Regulating MicroRNA-221 Resulting in the Inactivation of the PTEN/PI3K/AKT Pathway in Liver Cancer. Molecules 2019, 24, 4384. [CrossRef]

68. Roy, A.; Srivastava, M.; Saqib, U.; Liu, D.; Faisal, S.M.; Sugathan, S.; Bishnoi, S.; Baig, M.S. Potential therapeutic targets for inflammation in toll-like receptor 4 (TLR4)-mediated signaling pathways. Int. Immunopharmacol. 2016, 40, 79-89. [CrossRef]

69. Bie, B.; Sun, J.; Li, J.; Guo, Y.; Jiang, W.; Huang, C.; Yang, J.; Li, Z. Baicalein, a Natural Anti-Cancer Compound, Alters MicroRNA Expression Profiles in Bel-7402 Human Hepatocellular Carcinoma Cells. Cell Physiol. Biochem. 2017, 41, 1519-1531. [CrossRef] 
70. Bie, B.; Sun, J.; Guo, Y.; Li, J.; Jiang, W.; Yang, J.; Huang, C.; Li, Z. Baicalein: A review of its anti-cancer effects and mechanisms in Hepatocellular Carcinoma. Biomed. Pharmacother. 2017, 93, 1285-1291. [CrossRef]

71. Li, B.; Xu, N.; Wan, Z.; Ma, L.; Li, H.; Cai, W.; Chen, X.; Huang, Z.; He, Z. Isobavachalcone exerts anti-proliferative and pro-apoptotic effects on human liver cancer cells by targeting the ERKs/RSK2 signaling pathway. Oncol. Rep. 2019, 41, 3355-3366. [CrossRef] [PubMed]

72. Liu, X.F.; Long, H.J.; Miao, X.Y.; Liu, G.L.; Yao, H.L. Fisetin inhibits liver cancer growth in a mouse model: Relation to dopamine receptor. Oncol. Rep. 2017, 38, 53-62. [CrossRef] [PubMed]

73. Lu, Q. Transforming growth factor-beta1 protects against pulmonary artery endothelial cell apoptosis via ALK5. Am. J. Physiol. Lung Cell. Mol. Physiol. 2008, 295, L123-L133. [CrossRef] [PubMed]

74. Baarsma, H.A.; Spanjer, A.I.; Haitsma, G.; Engelbertink, L.H.; Meurs, H.; Jonker, M.R.; Timens, W.; Postma, D.S.; Kerstjens, H.A.; Gosens, R. Activation of WNT/ $\beta$-catenin signaling in pulmonary fibroblasts by TGF- $\beta_{1}$ is increased in chronic obstructive pulmonary disease. PLoS ONE 2011, 6, e25450. [CrossRef]

75. Zhao, X.; Jiang, K.; Liang, B.; Huang, X. Anticancer effect of xanthohumol induces growth inhibition and apoptosis of human liver cancer through NF-kB/p53-apoptosis signaling pathway. Oncol. Rep. 2016, 35, 669-675. [CrossRef]

76. Kunnimalaiyaan, S.; Sokolowski, K.M.; Balamurugan, M.; Gamblin, T.C.; Kunnimalaiyaan, M. Xanthohumol inhibits Notch signaling and induces apoptosis in hepatocellular carcinoma. PLoS ONE 2015, 10, e0127464. [CrossRef]

77. Srigopalram, S.; Jayraaj, I.A.; Kaleeswaran, B.; Balamurugan, K.; Ranjithkumar, M.; Kumar, T.S.; Park, J.I.; Nou, I.S. Ellagic acid normalizes mitochondrial outer membrane permeabilization and attenuates inflammation-mediated cell proliferation in experimental liver cancer. Appl. Biochem. Biotechnol. 2014, 173, 2254-2266. [CrossRef]

78. Souza, R.P.; Bonfim-Mendonça, P.S.; Gimenes, F.; Ratti, B.A.; Kaplum, V.; Bruschi, M.L.; Nakamura, C.V.; Silva, S.O.; Maria-Engler, S.S.; Consolaro, M.E. Oxidative Stress Triggered by Apigenin Induces Apoptosis in a Comprehensive Panel of Human Cervical Cancer-Derived Cell Lines. Oxidative Med. Cell Longev. 2017, 2017, 1512745. [CrossRef]

79. Sundaram, M.K.; Raina, R.; Afroze, N.; Bajbouj, K.; Hamad, M.; Haque, S.; Hussain, A. Quercetin modulates signaling pathways and induces apoptosis in cervical cancer cells. Biosci. Rep. 2019, 8, BSR20190720. [CrossRef]

80. Hussain, A.; Harish, G.; Prabhu, S.A.; Mohsin, J.; Khan, M.A.; Rizvi, T.A.; Sharma, C. Inhibitory effect of genistein on the invasive potential of human cervical cancer cells via modulation of matrix metalloproteinase-9 and tissue inhibitors of matrix metalloproteinase-1 expression. Cancer Epidemiol. 2012, 36, e387-e393. [CrossRef]

81. Wang, Y.; Chen, Y.; Wang, J.; Chen, J.; Aggarwal, B.B.; Pang, X.; Liu, M. Xanthohumol, a prenylated chalcone derived from hops, suppresses cancer cell invasion through inhibiting the expression of CXCR4 chemokine receptor. Curr. Mol. Med. 2012, 12, 153-162. [CrossRef] [PubMed]

82. García-Zepeda, S.P.; García-Villa, E.; Díaz-Chávez, J.; Hernández-Pando, R.; Gariglio, P. Resveratrol induces cell death in cervical cancer cells through apoptosis and autophagy. Eur. J. Cancer Prev. 2013, 22, 577-584. [CrossRef] [PubMed]

83. Geybels, M.S.; Verhage, B.A.; Arts, I.C.; van Schooten, F.J.; Goldbohm, R.A.; van den Brandt, P.A. Dietary flavonoid intake, black tea consumption, and risk of overall and advanced stage prostate cancer. Am. J. Epidemiol. 2013, 177, 1388-1398. [CrossRef] [PubMed]

84. Venè, R.; Benelli, R.; Minghelli, S.; Astigiano, S.; Tosetti, F.; Ferrari, N. Xanthohumol impairs human prostate cancer cell growth and invasion and diminishes the incidence and progression of advanced tumors in TRAMP mice. Mol. Med. 2012, 18, 1292-1302. [CrossRef]

85. Shukla, S.; Bhaskaran, N.; Babcook, M.A.; Fu, P.; Maclennan, G.T.; Gupta, S. Apigenin inhibits prostate cancer progression in TRAMP mice via targeting PI3K/Akt/FoxO pathway. Carcinogenesis 2014, 35, 452-460. [CrossRef]

86. Sharmila, G.; Athirai, T.; Kiruthiga, B.; Senthilkumar, K.; Elumalai, P.; Arunkumar, R.; Arunakaran, J. Chemopreventive effect of quercetin in MNU and testosterone induced prostate cancer of Sprague-Dawley rats. Nutr. Cancer 2014, 66, 38-46. [CrossRef]

87. Pitchakarn, P.; Chewonarin, T.; Ogawa, K.; Suzuki, S.; Asamoto, M.; Takahashi, S.; Shirai, T.; Limtrakul, P. Ellagic acid inhibits migration and invasion by prostate cancer cell lines. Asian Pac. J. Cancer Prev. 2013, 14, 2859-2863. [CrossRef]

88. Erdogan, S.; Doganlar, O.; Doganlar, Z.B.; Serttas, R.; Turkekul, K.; Dibirdik, I.; Bilir, A. The flavonoid apigenin reduces prostate cancer CD44(+) stem cell survival and migration through PI3K/Akt/NF-kB signaling. Life Sci. 2016, 1, 77-86. [CrossRef] 
89. Lim, W.; Park, S.; Bazer, F.W.; Song, G. Naringenin-Induced Apoptotic Cell Death in Prostate Cancer Cells Is Mediated via the PI3K/AKT and MAPK Signaling Pathways. J. Cell Biochem. 2017, 5, 1118-1131. [CrossRef]

90. Suh, Y.A.; Jo, S.Y.; Lee, H.Y.; Lee, C. Inhibition of IL-6/STAT3 axis and targeting Axl and Tyro3 receptor tyrosine kinases by apigenin circumvent taxol resistance in ovarian cancer cells. Int. J. Oncol. 2015, 46, 1405-1411. [CrossRef]

91. Wu, D.; Li, J.; Hu, X.; Ma, J.; Dong, W. Hesperetin inhibits Eca-109 cell proliferation and invasion by suppressing the PI3K/AKT signaling pathway and synergistically enhances the antitumor effect of 5-fluorouracil on esophageal cancer in vitro and in vivo. RSC Adv. 2018, 8, 24434. [CrossRef]

92. Zhang, H.; Jiang, H.; Zhang, H.; Liu, J.; Hu, X.; Chen, L. Anti-tumor efficacy of phellamurin in osteosarcoma cells: Involvement of the PI3K/AKT/mTOR pathway. Eur. J. Pharmacol. 2019, 5, 172477. [CrossRef] [PubMed]

93. Lee, S.G.; Kim, B.; Yang, Y.; Pham, T.X.; Park, Y.K.; Manatou, J.; Koo, S.I.; Chun, O.K.; Lee, J.Y. Berry anthocyanins suppress the expression and secretion of proinflammatory mediators in macrophages by inhibiting nuclear translocation of NF-kappaB independent of NRF2-mediated mechanism. J. Nutr. Biochem. 2014, 25, 404-411. [CrossRef] [PubMed]

94. Edirisinghe, I.; Banaszewski, K.; Cappozzo, J.; McCarthy, D.; Burton-Freeman, B.M. Effect of black currant anthocyanins on the activation of endothelial nitric oxide synthase (eNOS) in vitro in human endothelial cells. J. Agric. Food Chem. 2011, 59, 8616-8624. [CrossRef]

95. Babu, P.V.; Liu, D.; Gilbert, E.R. Recent advances in understanding the anti-diabetic actions of dietary flavonoids. J. Nutr. Biochem. 2013, 24, 1777-1789. [CrossRef]

96. Suh, Y.; Afaq, F.; Johnson, J.J.; Mukhtar, H. A plant flavonoid fisetin induces apoptosis in colon cancer cells by inhibition of COX2 and Wnt/EGFR/NF-kappaB-signaling pathways. Carcinogenesis 2009, 30, 300-307. [CrossRef]

97. Vauzour, D.; Vafeiadou, K.; Rodriguez-Mateos, A.; Rendeiro, C.; Spencer, J.P. The neuroprotective potential of flavonoids: A multiplicity of effects. Genes Nutr. 2008, 3, 115-126. [CrossRef]

98. De Andrade Teles, R.; Diniz, T.; Costa Pinto, T.; De Oliveira Júnior, R.; Gama, E.; Silva, M.; De Lavor, É.; Fernandes, A.; De Oliveira, A.; De Almeida Ribeiro, F.; et al. Flavonoids as therapeutic agents in Alzheimer's and Parkinson's diseases: A systematic review of preclinical evidences. Oxidative Med. Cell. Longev. 2018, 2018, 1-21. [CrossRef]

99. Spagnuolo, C.; Moccia, S.; Russo, G. Anti-inflammatory effects of flavonoids in neurodegenerative disorders. Eur. J. Med. Chem. 2018, 153, 105-115. [CrossRef]

100. Testai, L. Flavonoids and mitochondrial pharmacology: A new paradigm for cardioprotection. Life Sci. 2015, 135, 68-72. [CrossRef]

101. Pan, M.H.; Lai, C.S.; Hsu, P.C.; Wang, Y.J. Acacetin induces apoptosis in human gastric carcinoma cells accompanied by activation of caspase cascades and production of reactive oxygen species. J. Agric. Food Chem. 2005, 53, 620-630. [CrossRef] [PubMed]

102. Adams, R.H.; Alitalo, K. Molecular regulation of angiogenesis and lymphangiogenesis. Nat. Rev. Mol. Cell Biol. 2007, 8, 464-478. [CrossRef]

103. Chung, A.S.; Lee, J.; Ferrara, N. Targeting the tumour vasculature: Insights from physiological angiogenesis. Nat. Rev. Cancer 2010, 10, 505-514. [CrossRef] [PubMed]

104. Zhang, D.Y.; Wu, J.; Ye, F. Inhibition of cancer cell proliferation and p ros-t aglandin E2 synthesis by $\mathrm{S}$ cutellaria baicalensis. Cancer Res. 2003, 63, 4037. [PubMed]

105. Zhu, S.; Yang, C.; Zhang, L.; Wang, S.; Ma, M.; Zhao, J.; Song, Z.; Wang, F.; Qu, X.; Li, F.; et al. Development of M10, myricetin-3-O- $\beta$-d-lactose sodium salt, a derivative of myricetin as a potent agent of anti-chronic colonic inflammation. Eur. J. Med. Chem. 2019, 174, 9-15. [CrossRef] [PubMed]

Publisher's Note: MDPI stays neutral with regard to jurisdictional claims in published maps and institutional affiliations.

(C) 2020 by the authors. Licensee MDPI, Basel, Switzerland. This article is an open access article distributed under the terms and conditions of the Creative Commons Attribution (CC BY) license (http://creativecommons.org/licenses/by/4.0/). 